\title{
Creating Designs to Improve Consumer's Awareness and Purchasing Behavior towards Ethical Fashion
}

\author{
Olfat Shawki Mohamed Mansour \\ Apparel Department, Helwan University, Cairo, Egypt \\ Fashion Design Department, Qassim University, Buraidah, Saudi Arabia
}

\begin{abstract}
Apparel industry has a crucial impact on environment. In order to fight against these environmental impacts, there is a substantial development of the ethical fashion. There is a wide variety of ethical issues affecting the fashion industry and the consumer. Consumers' concerns and beliefs about, knowledge and support for ethical issues can effectively enhance their reception of ethical fashion and shape their purchase behavior. This research aims to improve the consumers' awareness and change his purchasing behavior to be more ethically, through creating printing designs which reflect the ethical fashion values and concepts on proper $\mathbf{T}$-shirts for women. To investigate the influence of these designs, the researcher designed a questionnaire which has been conducted with women (18- 30 years). Results indicate that questionnaire Items were positive with an overall mean score of 4.88 (\% of mean $=97.6 \%)$. The majority of respondents agreed to with 11 T-shirts.
\end{abstract}

Keywords: Ethical fashion, sustainability, consumerism, ethical awareness, purchasing behavior.

\section{INTRODUCTION}

Nowadays, one can observe that there is a global growth of people's concerns regarding the environment. Individuals recognize the need to act differently in a world that suffers from the overconsumption of the human beings [1]. Consumers are increasingly becoming aware that their consumption is integral part of the global political and economic system [2]. It is important for companies to take notice of shifting consumer behavior, which often derives from ethical concerns [3].

Fashion industry has been subject to pivotal trends over the last two to three decades. The industry has evolved into a complex, fragmented, global system which at its very core is based on the notion of continual consumption of the 'new' and the discard of the 'old'. The emergence of the 'fast fashion' business model has increased the introduction of trends leading to premature product replacement and fashion obsolescence. It also has major negative environmental and social impacts, particularly on those at the bottom of the supply chain. [4]\&[5]

The fashion industry has been increasingly under the spotlight as a significant contributor to global environmental and social issues. Life-cycle assessment is a standard tool used to investigate the environmental impacts of all stages of a product's life [6] from raw materials through to design, manufacture, packaging, logistics, consumer use and post-use disposal. [7]

The ever-increasing temptation of cheap and fashionable clothing creates a deep contradiction between consumers' concerns for sustainability and their purchase behavior in the clothing industry. [8] A socially conscious consumer considers his or her purchasing consequences to achieve social change and take into account sustainability arguments. Consumers that predominantly consider product information in relation to environmental sustainable action are therefore identified as being strongly motivated by environmental values. [9]

Consumers must taking into account environmental and social sustainable values. Ethical consumers are more likely to judge organizations in assessing their ethical preferences before purchase. [10]

\subsection{Ethical Fashion Definition}

According to Joergens [11] ethical fashion is defined as "fashionable clothes that incorporate fair trade principles with sweatshop free labour conditions while not harming the environment or workers by using biodegradable and organic cotton". Ethical fashion may be also understood as "fashion with conscience".

Another definition is provided by the Ethical Fashion Forum: "ethical fashion represents an approach to the design, sourcing and manufacture of clothing which maximizes benefits to people and communities while minimizing impact on the environment" [12].

Ethical fashion refers to clothing that is designed for long lifetime use that is produced in an ethical production system, 
ISSN (online): 2581-3048

perhaps even locally, causing little or no environmental impact and making use of eco-labeled or recycled materials. [13]

\subsection{Ethical Consumer}

The ethical consumer has been defined as someone who "considers environmental issues, animal issues and ethical issues, including oppressive regimes and armaments, when shopping" [14]. Consumer behaviour could be described as fickle and very unpredictable. In preference to the term ethical consumer, it has been suggested that consumer social responsibility is used, which can be defined as the deliberate choice to make certain consumption choices based on personal and ethical beliefs [15]. Carrigan and Attalla [16] believe that the consumer importance of self continues to emerge, where if unethical behaviour affected them personally, they may care more.

\subsubsection{Ethical Awareness and Knowledge}

An underlying argument within the debate of ethical awareness levels is the idea of consumers having enough knowledge (or not) in order to make a well-informed decision. [15] A fully informed consumer is unattainable; it is also thought that growing levels of ethical awareness is due to academic interest, increased media levels and a greater choice of ethical products. [17]

Niinimaki [18] believes that there is a direct correlation between the quantity of information provided and more wellinformed, educated decisions being made. It has been proven that it is easier to educate consumers outside of a store situation and have in-store advertisement as a confirmation of knowledge.

With the rise of consumer awareness, ethical consumerism is becoming a significant driving force in the clothing industry. Many clothing brands are becoming sensitive to the ethical issues relevant to the clothing industry and employing media strategies to put out their stand on these issues. [19]

\subsubsection{Ethical Purchasing Behavior}

The decision to buy an ethical brand over a conventional alternative is influenced by a number of factors including; brand awareness, the importance of other product criteria, the extent to which buying and ethical product implies an inconvenience or product compromise, if at all, and of course price. [20]

James [15] mentioned that the most important purchasing criteria is price, value, quality and brand familiarity. The fact that ethical is not one of the purchasing priorities indicates that consumers will look for all or some of these factors in a product before ethics is even considered. In addition to socioeconomic positioning, it is thought that culture also plays a role within the purchasing hierarchy.

Ethical purchasing is often related to the trade off or compromise of factors such as price, style of choice in order to be able to purchase ethical goods. The term flexibility has been applied to ethical purchasing, as the need for balancing ethical ethics and values with the practicality of everyday life is needed. [21]

Pollari [8] indicates the Factors influencing purchase behavior of ethical fashion, as follows: Beliefs about sweatshop and environmental issues, Attitude towards buying ethical fashion, and Intention of buying ethical fashion.

\section{MATERIALS AND METHOD}

In order to demonstrate the applied part of this research, a review of the previous literature is done. First of all, the attention is placed on a brief understanding of ethical fashion, and consumers' awareness and behavior when purchasing garments.

\subsection{Creating and Implementing Printing Designs}

Paulins \& Hillery [22] indicate that Consumers' knowledge about products and their relative ethical impacts are major factors that contribute to ethical consumerism. So the present research seeks to improve the consumer's knowledge about ethical values by creating printing designs which reflect the ethical fashion values and concepts, such as: ethical fashion and sustainable fashion, environmentally friendly fabrics and organic cotton, clothing consumption, sweatshops, how to shop ethically, and how to build ethical closet and wardrobe. The printing designs are suitable to print on T-shirts for women in the age group (18-30 years). Adobe illustrator cc 2019 software program was used to help in drawing and coloring the designs.

The researcher used the style of additive visual elements, illustrations, symbols, and meanings, which were truly helped in defining the ethical fashion values. The researcher followed the six laws of perceptual organization particularly useful in creating printing designs-similarity, proximity, continuation, figure-ground relationships, closure, and assimilation. These have been shown to have a significant relationship with consumer responses, including positive affect, perceptions of quality, recognition, and consensus in meaning. The more literal an illustrative design is, the less work a potential consumer needs to do to interpret. Color can be an effective means of creating and sustaining design and corporate images in consumers' minds. So the researcher used the natural 
ISSN (online): 2581-3048

dimensions of color: hue, saturation, and brightness to make the designs more attractive to the consumers.

Digital printing (Dry thermal transfer method) was used to print creating designs on $\mathrm{T}$-shirts which are suitable for women in the age group (18-30 years). Printing was done first by printing on the paper using special printing ink containing a sublimable disperse dye at high concentrations. Okidata Pro 920WT Transfer Printer was used to print the creating designs on customized transfer paper. Then placing the printed paper on the $\mathrm{T}$-shirt and pressing them under heat to sublime the sublimable dye and condense it onto the T-shirt.

The researcher deliberated to buy $\mathrm{T}$-shirts made of organic blend cotton and sustainable cotton to emphasize the ethical values for the consumers who see the organic blend cotton tag on the T-shirts.

\subsection{Constructing and Investigating of the Research Tool}

To investigate the research aim, a questionnaire was designed and constructed (Appendix 1). The sample of the questionnaire will be composed by Saudi women between 18 and 30 years. The respondents are chosen first of all because they will represent the consumer of tomorrow. Young people are also more interested in fashion and more educated than older ones. According to the International Institute of Sustainable Development, the most responsive age group is young adults who are often influenced by their children and women who tend to make purchasing decisions on behalf of men. [23]

The questionnaire consisted of closed items which helped in avoiding respondent fatigue and also improves the response rate. Respondents were asked to rate the degree of their agreement. A five-point Likert-scale was used, in which " 1 " represented "strongly disagree" and " 5 " represented "strongly agree". Prior to conducting the final research, a pre-test was conducted to assess the clarity of the questionnaire and its suitability to the consumers. According to Churchill and Iacobucci [24] a pre-test is used to determine the clarity of items, the format of the survey as well as the length and instructions required for the overall questionnaire. Before starting with the actual data collection, a pre-test of the developed questionnaire was distributed among seven test respondents. To keep the conditions of the pilot study similar to the main research and to get a close match to the desired sample, the chosen respondents were Saudi women in the age group (18-30 years). The purpose of conducting a pre-test was two-fold. First was to ensure the reliability and the validity of the questionnaire and second, that the respondents were able to comprehend and answer the questions as expected and intended.
The respondents found the survey lengthy. Thus, some of the items were removed and the items were chosen as such their removal would not affect the results of the survey. The items of the questionnaire become 11 after removing some items. The time required by the respondents to fill out the survey was also measured which turned out to be approximately 5-9 minutes. Necessary changes and corrections in the questionnaire were performed based on the comments from the respondents of the pre-test and the questionnaire was made ready for distribution.

\section{RESULTS AND DISCUSSION}

\subsection{Presentation of Printing Designs}

The research sixteen printing designs were created to carry various ethical values. The designs were presented with clarifying of each design ethical value as follows:

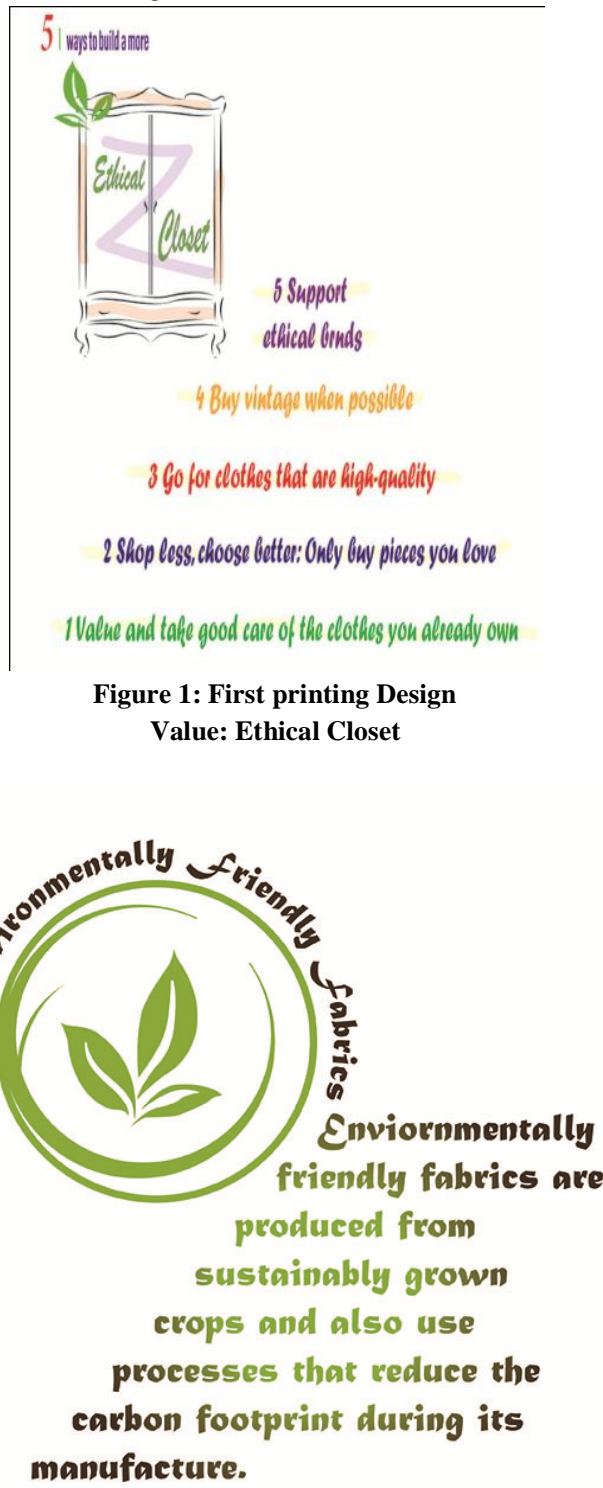

Figure 2: Second printing Design Value: Sustainable Fabrics 


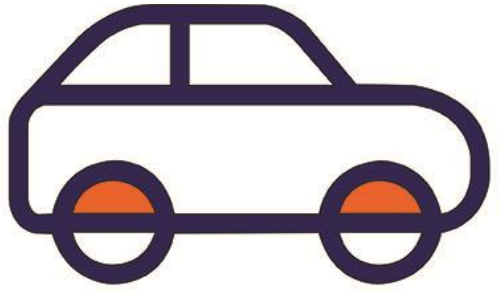

CLOTHING CONSUMPTION PRODUCES 1.5 TONNES OF CO2 $X$ HOUSEHOLD X YEAR.

\section{THE EQUAIVALENT OF DRIVING 600 CARS}

Figure 3: Third printing Design Value: Clothing Consumption Impacts

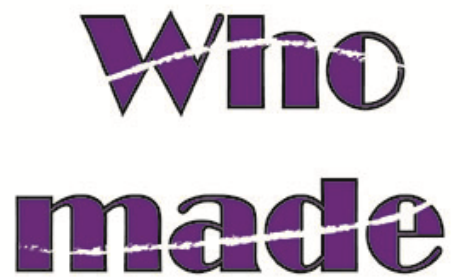
TIPY

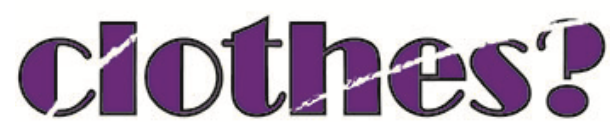

Figure 4: Fourth printing Design Value: Ethical Labor

\section{-SHOP ETHICALY.}

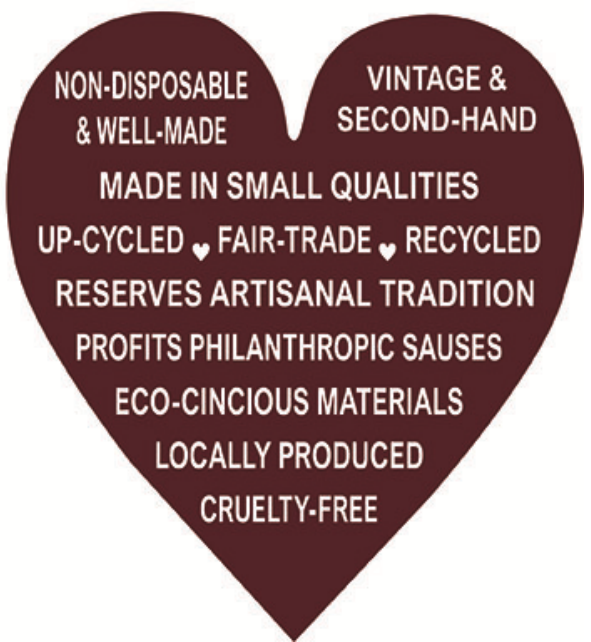

Figure 5: Fifth printing Design

Value: Ethical Purchasing

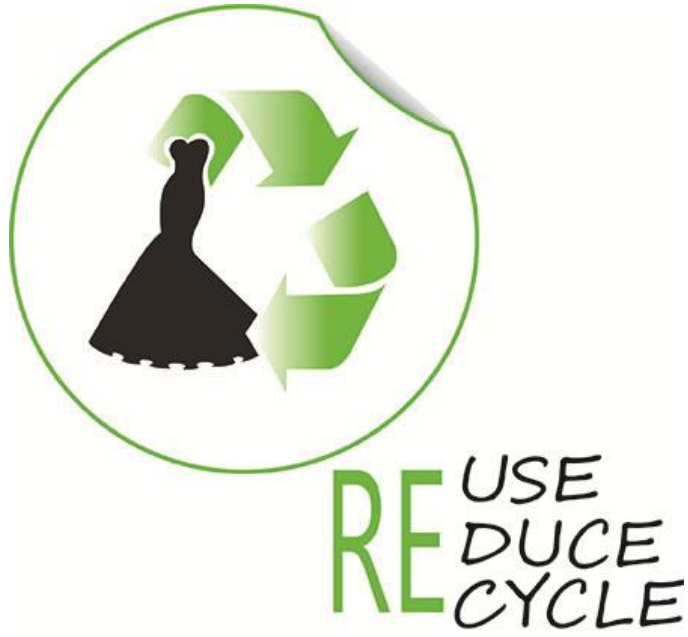

Figure 6: Sixth printing Design Value: Clothing Recycle

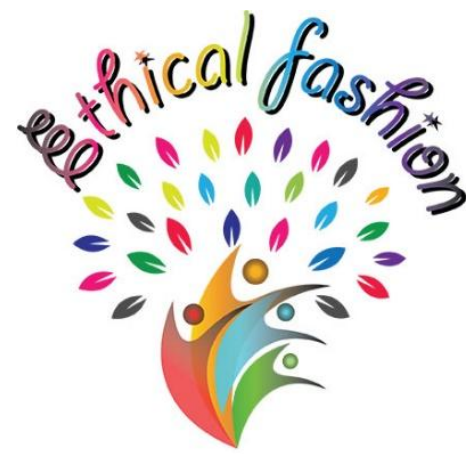

is the recognition that there are human beings behind the clothes

that we wear

Figure 7: Seventh printing Design Value: Ethical Labor

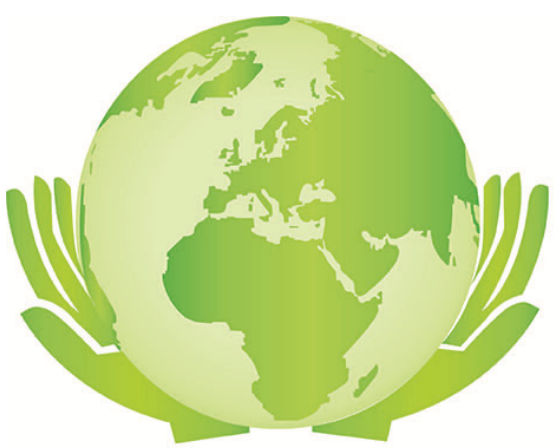

\section{Fashion shouldn't} cost the earth.

Figure 8: Eighth printing Design

Value: Reduce Impact on Environment 
4 SIMPLE STEPS FOR AN

ETHICAL

WORDROBE

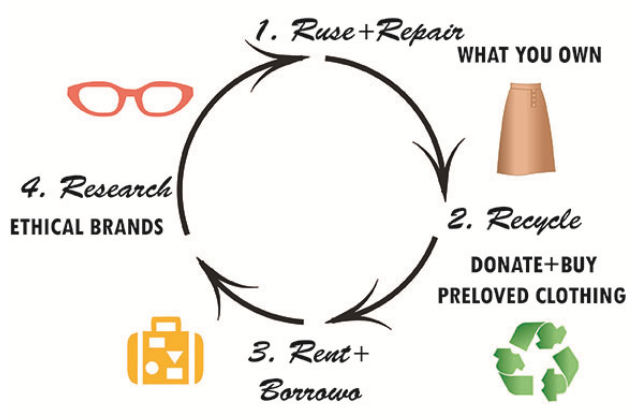

OCCASIONAL WEAR ITEMS

Figure 9: Ninth printing Design

Value: Ethical Purchasing
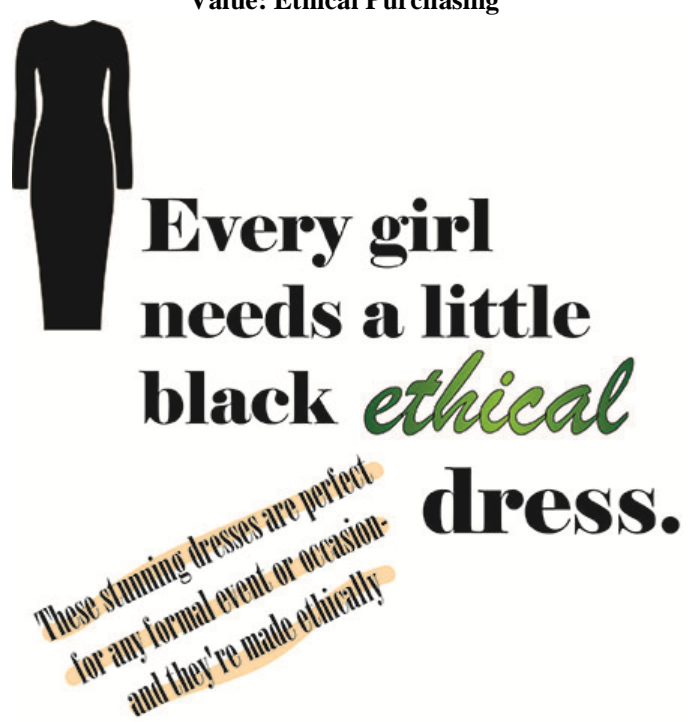

Figure 10: Tenth printing Design

Value: Long Lasting Clothes

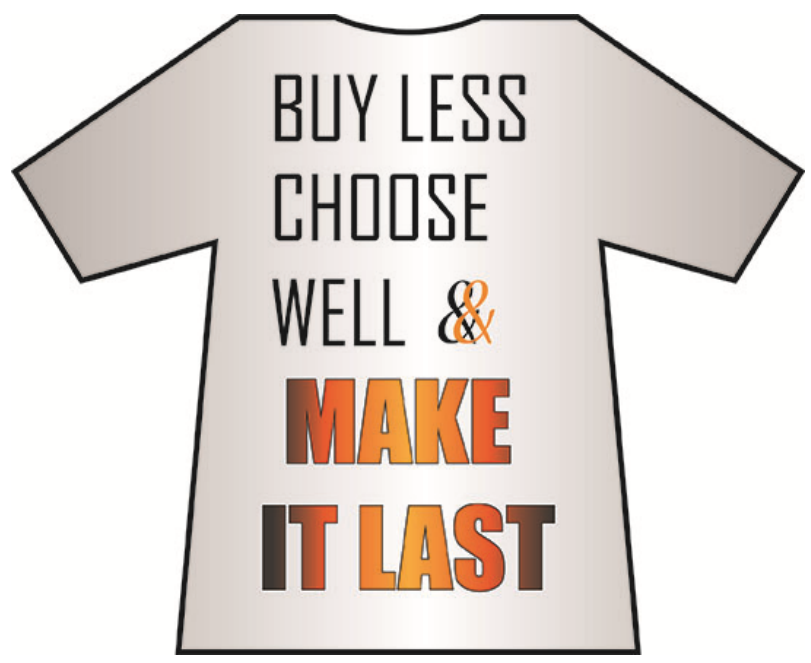

Figure 11: Eleventh printing Design Value: Ethical Purchasing
https://doi.org/10.47001/IRJIET/2020.407007

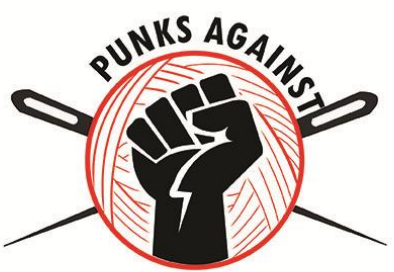

Sweatshop

Sweatshop refers to an employer who exploits workers "by means of Iow wagles, excesssive working hours, under age emplougees, or other exploitative practices, rrequently but not exclusively in developing economies where labor laws and worker's rightls can be less rigurorous". "The low pay, long hour's, poor working condilions and chlidd labor are the most commonoly recognizzed characteristics of a sweatshop.

long hours, poor working conditions and chilld lathor are the most commononly recoggnized characteristics of a sweatshop

Figure 12: Twelfth printing Design Value: Sweatshops Impacts

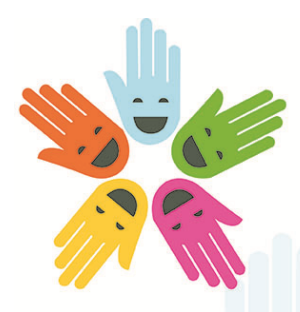

STYLE IS

KNOWING THAT THE HANDS THAT MADE YOUR CLOTHES ARE HAPDY HANDS

Figure 13: Thirteenth printing Design Value: Ethical Labor
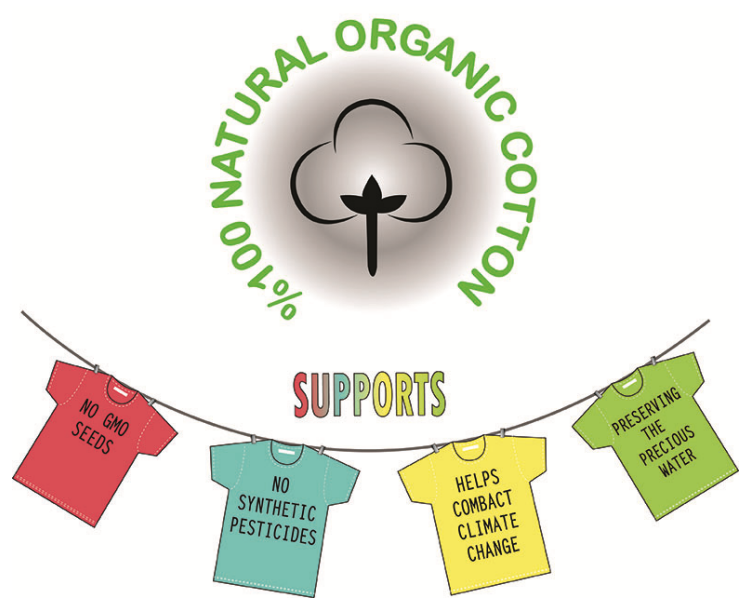

Figure 14: Fourteenth printing Design Value: Organic Cotton 


\section{SYSTANANAD IS TASUION}

Sustainable fushion aims to produce garments using fabrics that are sourced sustainably, produced within an ethical process and will last longer thanks to a higher quality. The entire cycle of a garment firom its design to potencial uses and lifespan is considered in order:for it to be classified as sustainable fashion.

Figure 15: Fifteenth printing Design

Value: Sustainable Fashion Organic Cotton

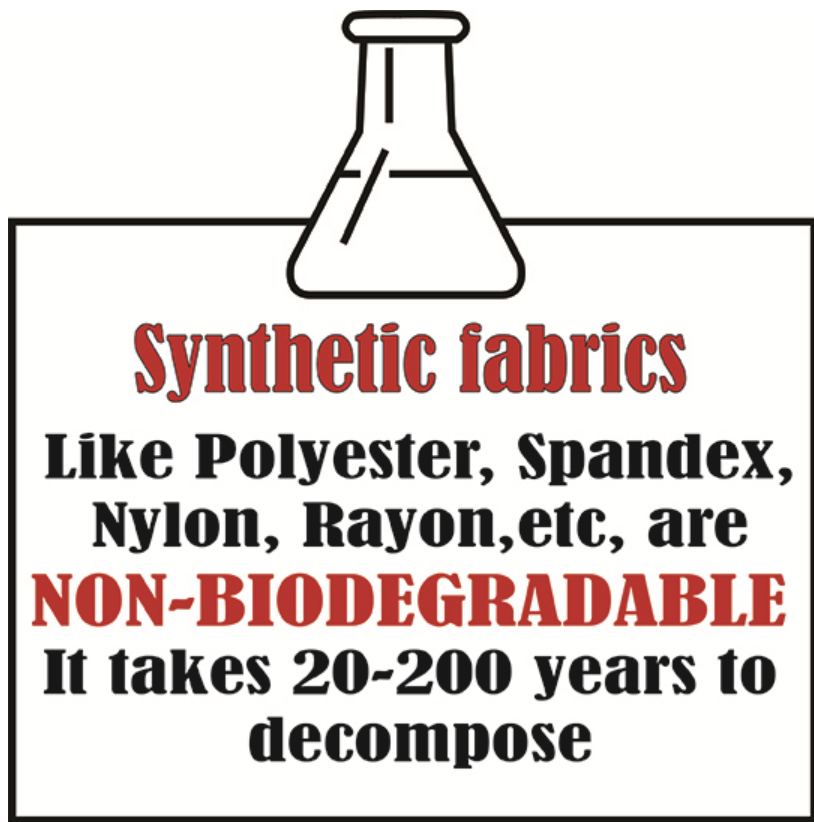

Figure 16: Sixteenth printing Design Value: Synthetic Fabrics Impacts

Eleven printing designs with different ethical values were chosen to print on organic blend cotton and sustainable cotton T-shirts by using dry thermal transfer printing method as follows:

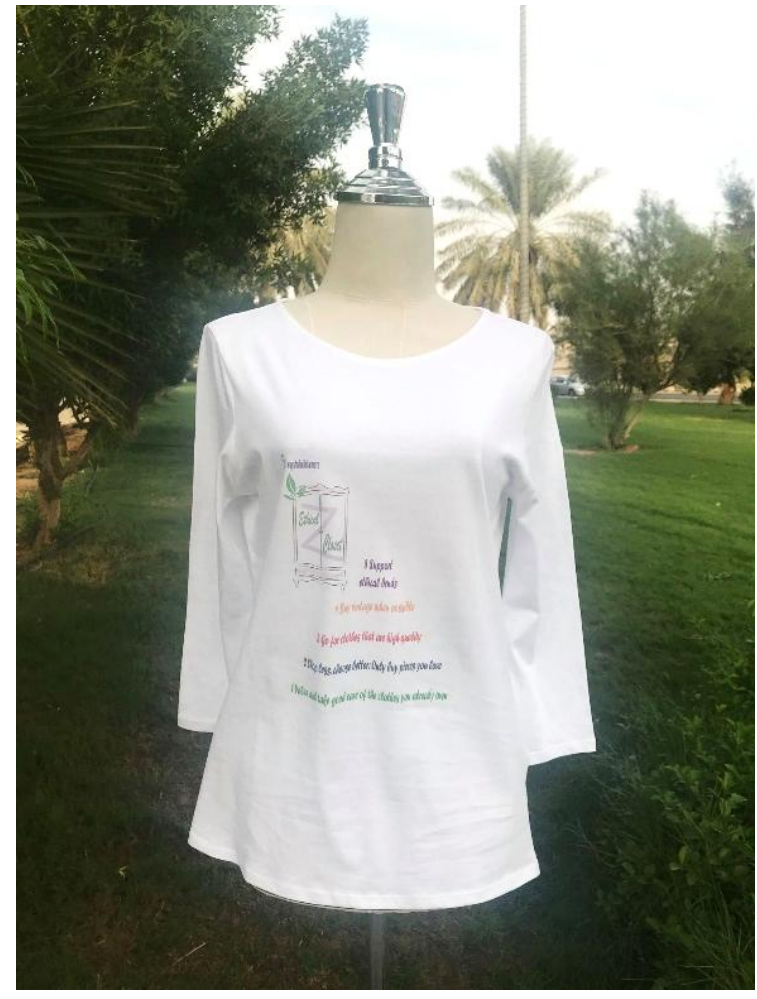

Figure 17: First printing T-shirt

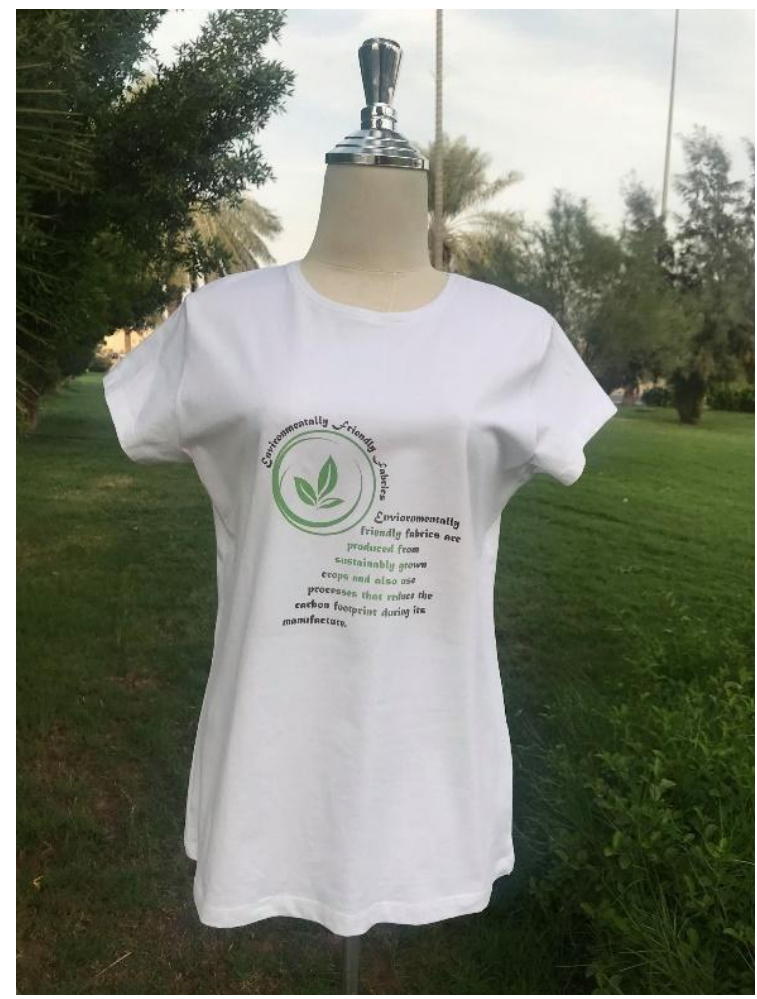

Figure 18: Second printing T-shirt 

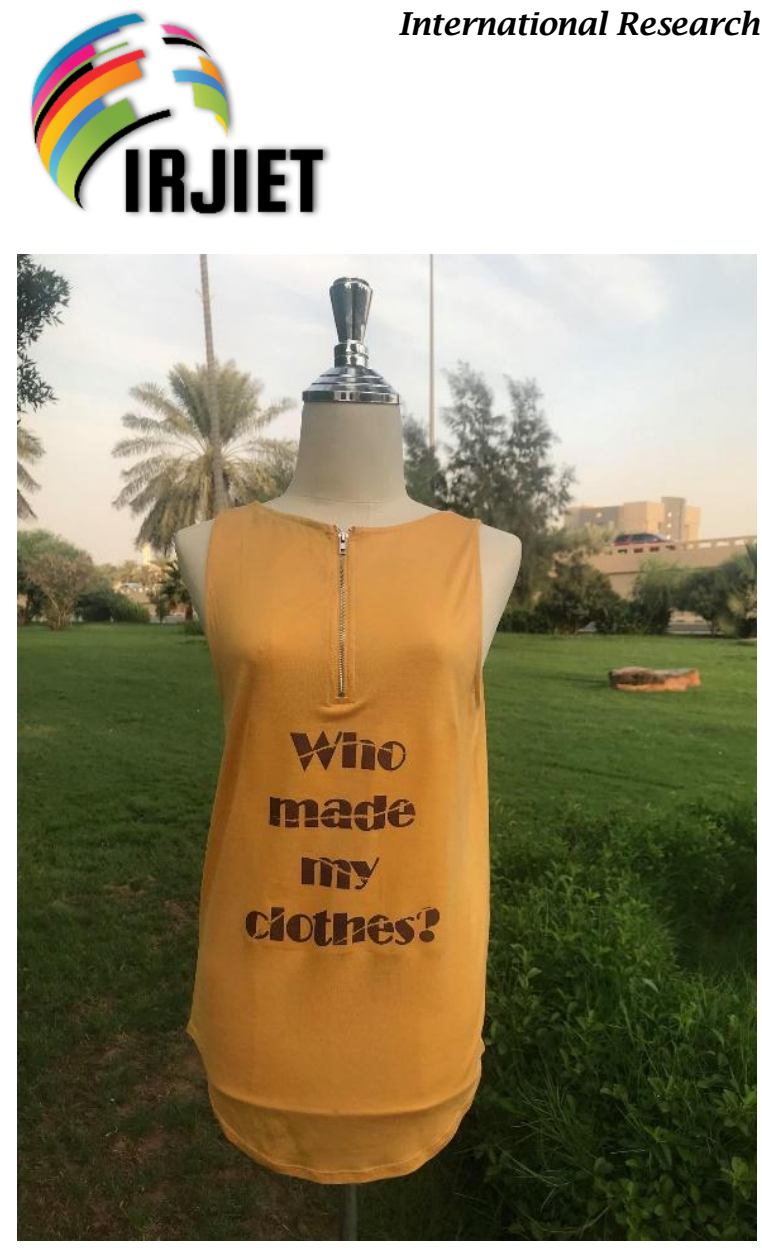

Figure 19: Third printing T-shirt

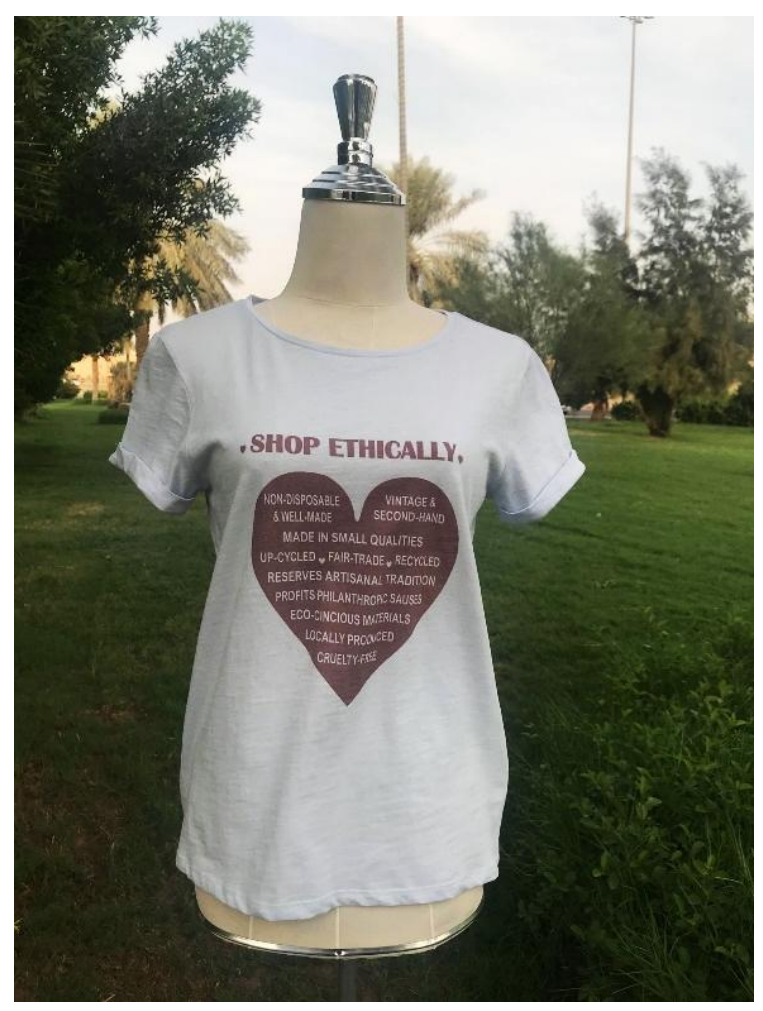

Figure 20: Fourth printing T-shirt
ISSN (online): 2581-3048

Volume 4, Issue 7, pp 40-52, July-2020 https://doi.org/10.47001/IRJIET/2020.407007

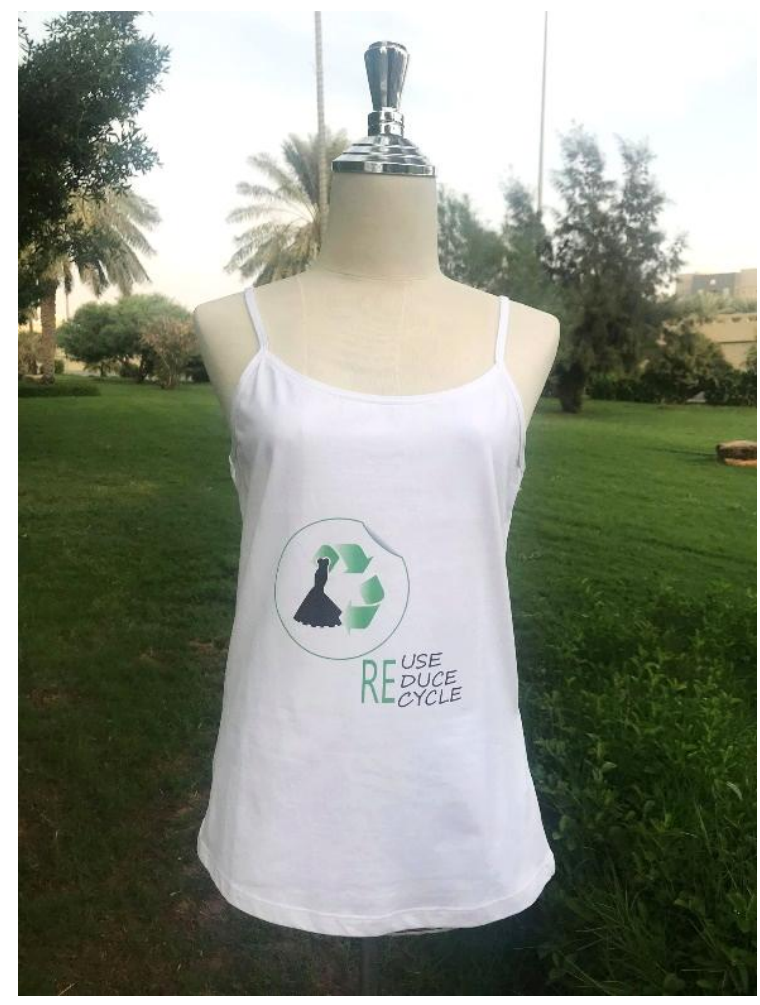

Figure 21: Fifth printing T-shirt

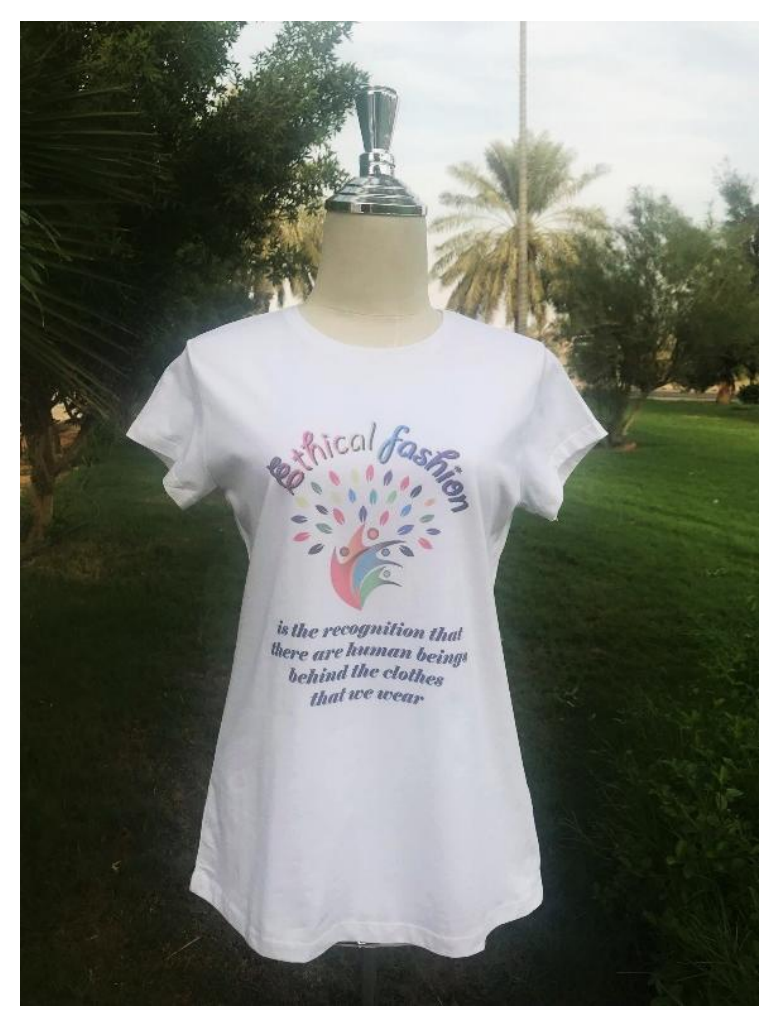

Figure 22: Sixth printing T-shirt 

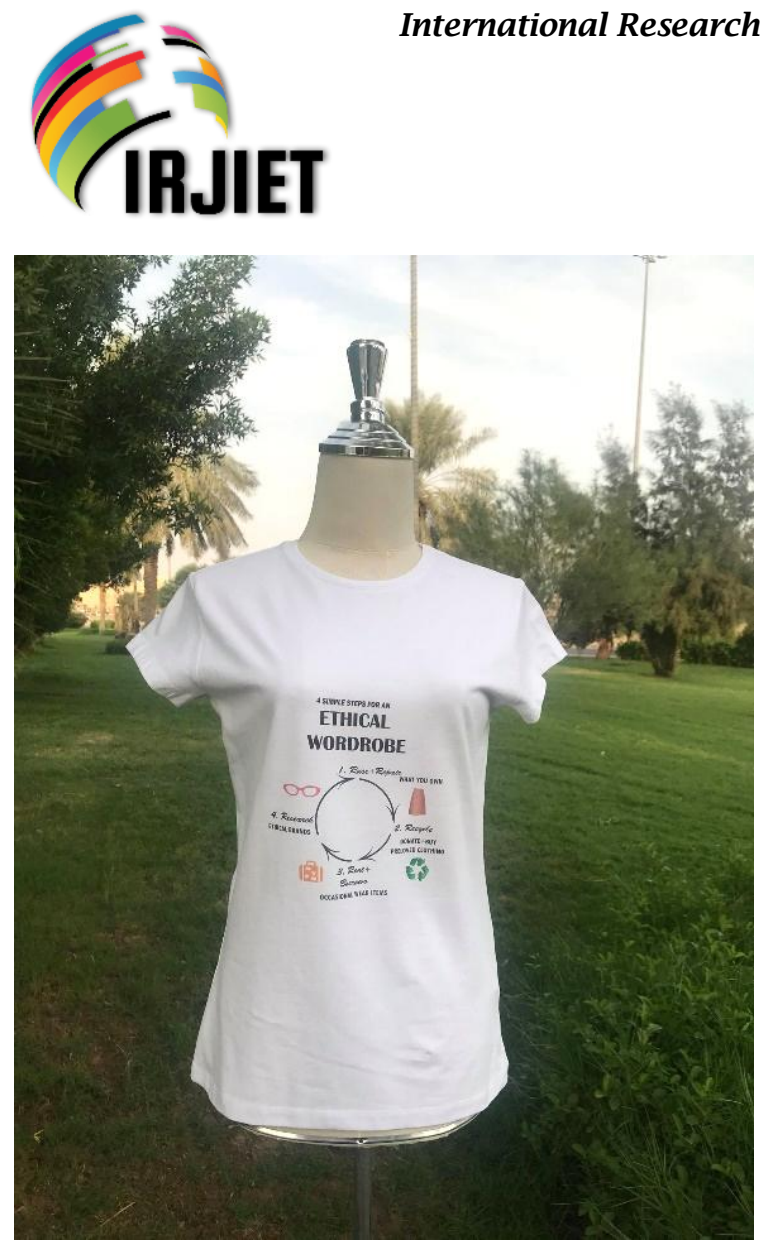

Figure 23: Seventh printing T-shirt

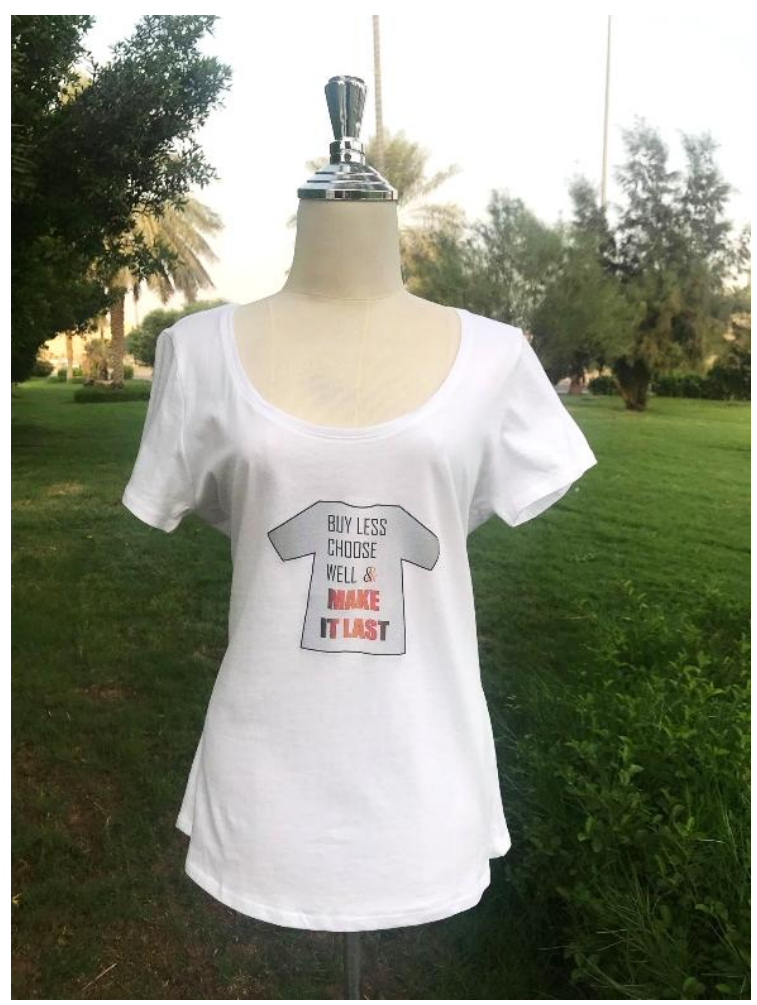

Figure 24: Eighth printing T-shirt
ISSN (online): 2581-3048

Volume 4, Issue 7, pp 40-52, July-2020 https://doi.org/10.47001/IRJIET/2020.407007

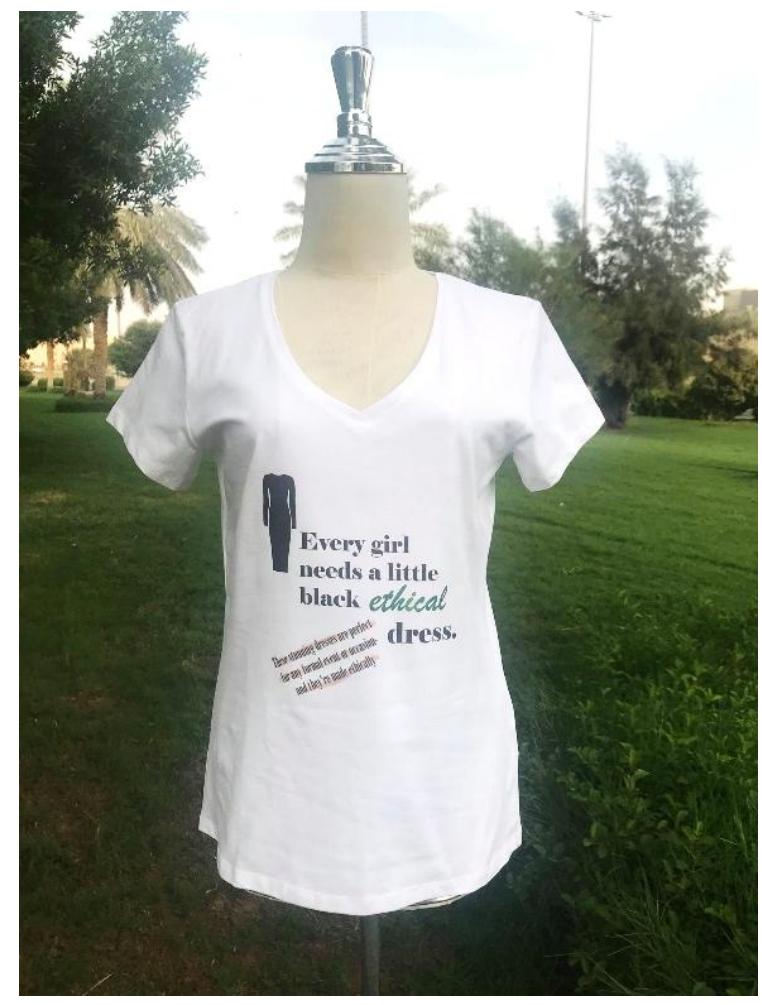

Figure 25: Ninth printing T-shirt

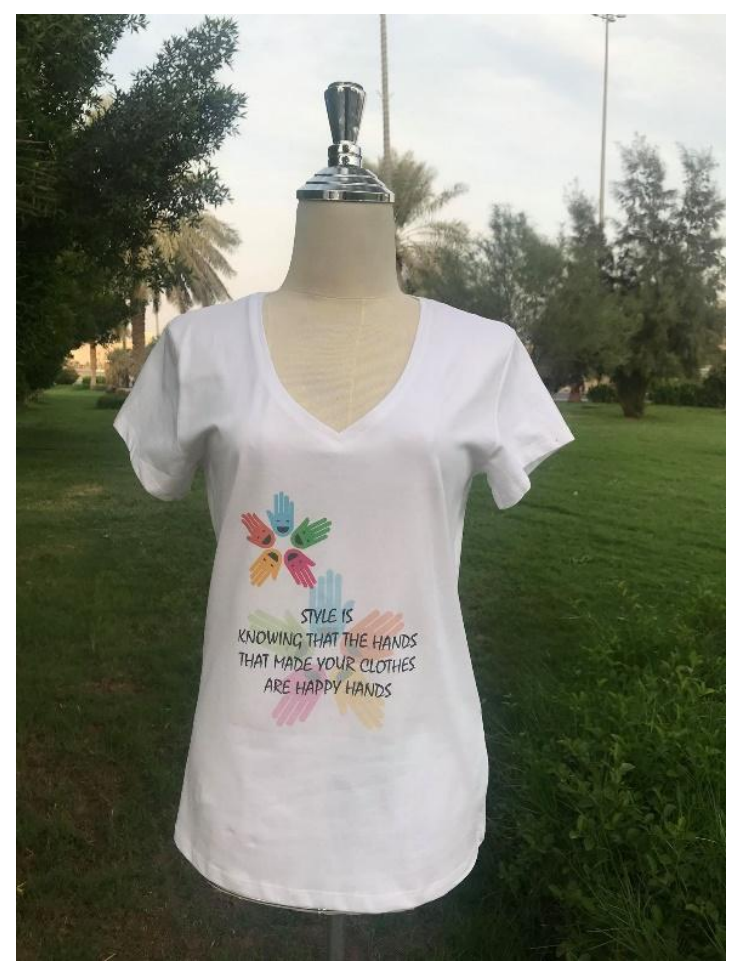

Figure 26: Tenth printing T-shirt 

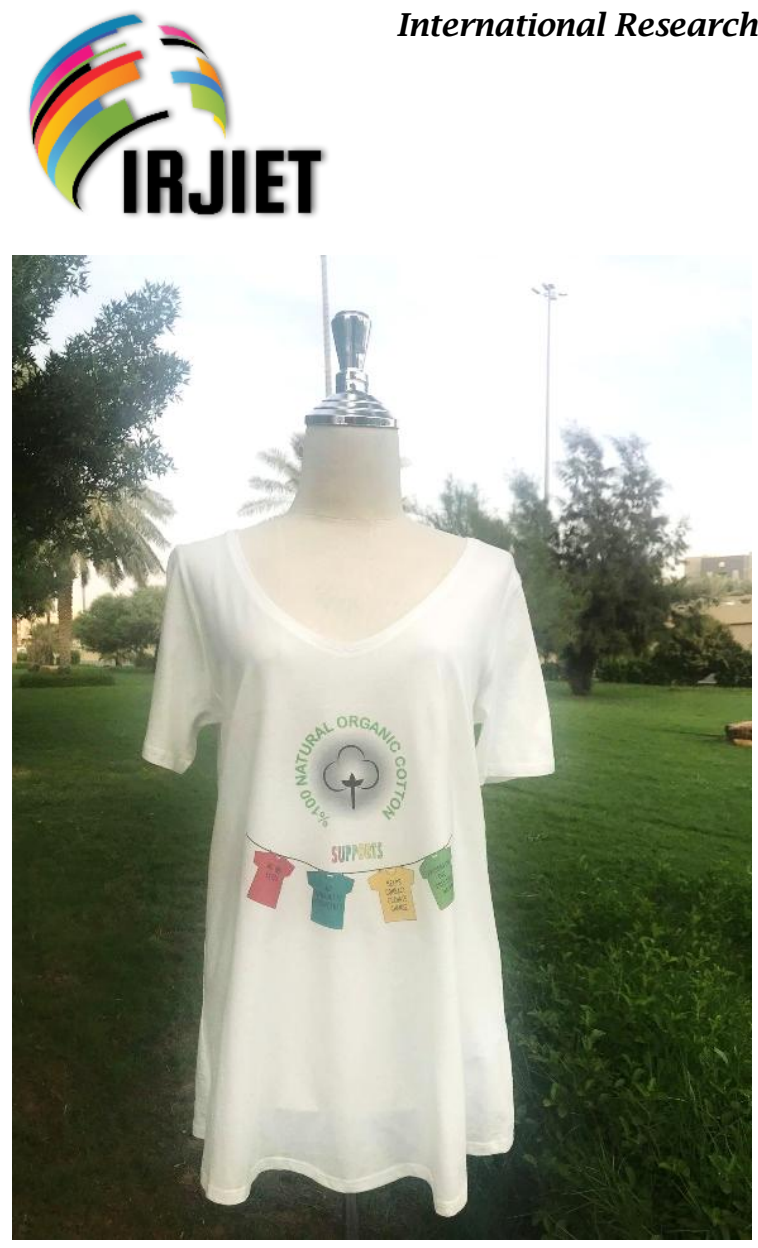

Figure 27: Eleventh printing T-shirt
ISSN (online): 2581-3048

Volume 4, Issue 7, pp 40-52, July-2020 https://doi.org/10.47001/IRJIET/2020.407007

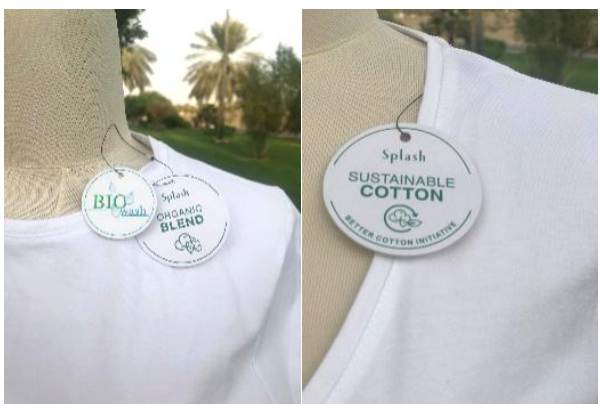

Figure 28: Sustainable cotton and organic blended cotton tags

The collection of qualitative and quantitative data was done through in-depth Interview. This method is chosen in order to get deep insight from respondent, ensure all the questions had been answered. The respondents were thirty one Saudi women between 18 and 30 years old. After collecting the data, it has been analyzed by IBM SPSS Statistics 25 . As the first analysis, the basic features of the data have been described with the descriptive statistics to provide simple summaries about respondents. After the quantitative data collection process had been completed, data analysis began.

The average rate of consumers' opinions in achieving the questionnaire items was calculated, as shown in table (1):

Table 1: Means and percentage of mean and responses for questionnaire items

\begin{tabular}{|c|c|c|c|c|c|c|c|c|c|c|c|c|c|}
\hline \multirow[b]{2}{*}{ Items } & \multirow[b]{2}{*}{ 音 } & \multirow[b]{2}{*}{ 尝 } & \multirow[b]{2}{*}{ 竭 } & \multirow[b]{2}{*}{ 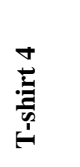 } & \multirow[b]{2}{*}{ 范 } & \multirow[b]{2}{*}{ 苞 } & \multirow[b]{2}{*}{ 范 } & \multirow[b]{2}{*}{ 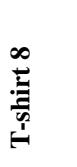 } & \multirow[b]{2}{*}{ 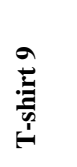 } & \multirow[b]{2}{*}{ 串 } & \multirow[b]{2}{*}{ ב } & \multicolumn{2}{|c|}{ overall } \\
\hline & & & & & & & & & & & & Mean & $\%$ \\
\hline Item1 & 5 & 5 & 3.97 & 5 & 5 & 5 & 5 & 5 & 5 & 4.29 & 5 & 4.84 & 96.8 \\
\hline Item2 & 5 & 5 & 4.29 & 5 & 4.29 & 5 & 5 & 4.94 & 5 & 4.9 & 4.94 & 4.85 & 97 \\
\hline Item3 & 4.9 & 4.94 & 4 & 5 & 5 & 5 & 5 & 4.83 & 5 & 4.97 & 5 & 4.88 & 97.6 \\
\hline Item4 & 4.83 & 5 & 5 & 5 & 4.35 & 5 & 5 & 5 & 5 & 5 & 5 & 4.93 & 98.6 \\
\hline Item5 & 4.74 & 4.71 & 3.81 & 5 & 4.74 & 4.52 & 4.94 & 3.97 & 4.29 & 5 & 4.97 & 4.61 & 92.2 \\
\hline Item6 & 5 & 5 & 5 & 5 & 4.94 & 5 & 5 & 5 & 5 & 5 & 5 & 4.99 & 99.8 \\
\hline Item7 & 5 & 5 & 4.65 & 5 & 4.84 & 5 & 5 & 5 & 4.97 & 4.94 & 5 & 4.95 & 99 \\
\hline Item8 & 4.52 & 5 & 4.94 & 4.48 & 5 & 5 & 4.71 & 4.83 & 5 & 5 & 5 & 4.86 & 97.2 \\
\hline Item9 & 5 & 4.94 & 4.35 & 5 & 4.94 & 5 & 4.97 & 4.29 & 5 & 5 & 5 & 4.86 & 97.2 \\
\hline Item10 & 4.84 & 5 & 5 & 5 & 4.48 & 5 & 5 & 4.52 & 5 & 5 & 5 & 4.89 & 97.8 \\
\hline Item11 & 5 & 5 & 4.94 & 5 & 4.9 & 5 & 5 & 5 & 5 & 5 & 4.9 & 4.98 & 99.6 \\
\hline & 4.89 & 4.96 & 4.54 & 4.95 & 4.77 & 4.96 & 4.97 & 4.76 & 4.93 & 4.92 & 4.98 & 4.88 & 97.6 \\
\hline overa & $\begin{array}{c}97.8 \\
\%\end{array}$ & $\begin{array}{c}99.2 \\
\%\end{array}$ & $\begin{array}{c}90.8 \\
\%\end{array}$ & $99 \%$ & $\begin{array}{c}95.4 \\
\%\end{array}$ & $\begin{array}{c}99.2 \\
\%\end{array}$ & $\begin{array}{c}99.4 \\
\%\end{array}$ & $\begin{array}{c}95.2 \\
\%\end{array}$ & $\begin{array}{c}98.6 \\
\%\end{array}$ & $\begin{array}{c}98.4 \\
\%\end{array}$ & $\begin{array}{c}99.6 \\
\%\end{array}$ & & \\
\hline
\end{tabular}


ISSN (online): 2581-3048

According to table I, the11 Items were positive with an overall mean score of $4.88(\%$ of mean $=97.6 \%)$. The majority of respondents agreed to with $11 \mathrm{~T}$-shirts.

The first item with the highest level of satisfaction was 'Buying ethical fashion is a good thing because it positively affects society and environment.' This had the highest mean score $(M=4.99$ and $99.8 \%)$. The second highest rated item was 'After understanding the ethical values that the printing design carry, I believe that by purchasing an item of ethical clothing, I could make a difference to the fashion negative impacts on society and environment.'. This also had the highest mean score $(M=4.98$ and 99.6). The third highest rated item was 'After understanding the ethical values that the T-shirt carry, Next time when I buy clothes, I will rather buy the ethically produced option.' This also had the highest mean score $(M=4.95$ and $99 \%)$. The fourth highest rated item was 'The materials used which generally clearly stated on the Tshirt tag confirmed me that the using of organic and sustainable fabrics reduces negative impacts on environment'. This also had the highest mean score ( $\mathrm{M}=4.93$ and $98.6 \%)$. The fifth highest rated item was 'Ethical issues that the printing design carry, improved my awareness toward the ethical fashion'. This also had the highest mean score $(\mathrm{M}=$ 4.89 and $97.8 \%$ ). The sixth highest rated item was 'I believe that the printing design succeeded in informing me about ethical issues in the fashion manufacturing'. This also had the highest mean score $(\mathrm{M}=4.88$ and 97.6\%). The seventh highest rated item was 'The printing design elements (symbols, colours, and Explanatory statements) helped me in understanding the ethical fashion values'. This also had the highest mean score ( $M=4.86$ and $97.2 \%)$. The eighth highest rated item 'The printing design helped in creating a favorable attitude towards ethical clothing'. This also had the highest mean score $(\mathrm{M}=4.86$ and $97.2 \%)$. The ninth highest rated item was ' $\mathrm{I}$ believe that the printing design is a message which encourages anyone to buy ethical fashion'. This also had the highest mean score $(M=4.85$ and 97\%). The tenth highest rated item was 'The ethical value in the printing design helped me to understand more about ethical fashion'. This also had the highest mean score $(\mathrm{M}=4.84$ and $96.8 \%)$. The eleventh highest rated item was 'I believe that I am informed about environmental and social issues through the ethical values that the printing design carry'. This also had the highest mean score $(\mathrm{M}=4.61$ and $92.2 \%)$.

The majority of respondents agreed to with 11 designs, as shown in Fig. (29)

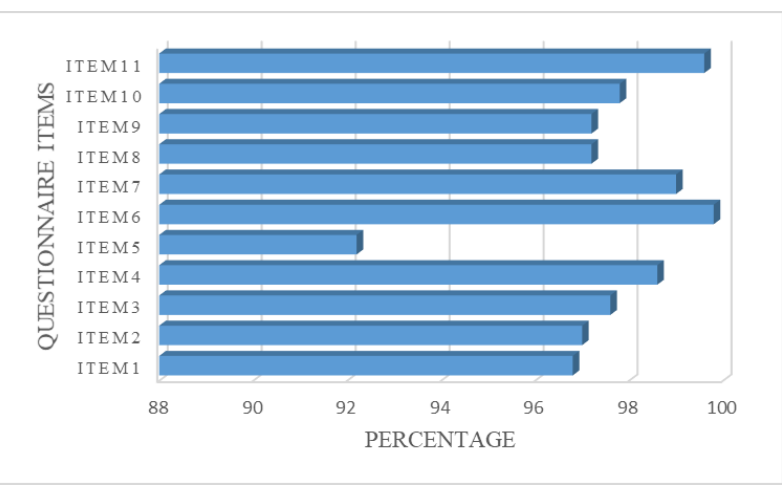

Figure 29: percentage of mean and respondents' interaction with questionnaire Items

Using one-way ANOVA, the F statistic test whether the T-shirts are all equal, that there are differences among the means of the $11 \mathrm{~T}$-shirts. A significant $\mathrm{F}$ value indicates that there are differences in the means, but it does not tell us where those differences are, by using LSD TEST we can find which T-shirts are differences.

ANOVAs were used to determine if statistically significant differences existed among $11 \mathrm{~T}$-shirts for 31 respondents. There were statistically significant differences based on sum of all questions between $11 \mathrm{~T}$-shirts for 31 respondents.

Table 2: Analysis of variance (ANOVA)
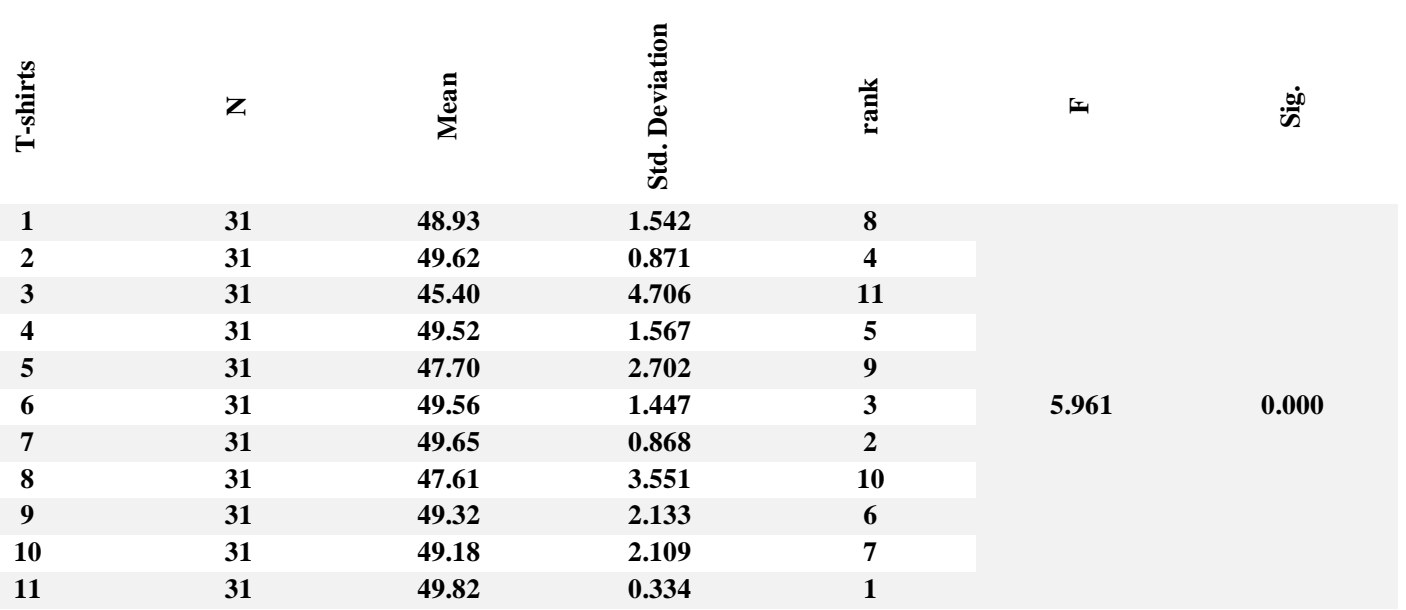
Table (2) shows the descriptive statistics of all T-shirts for all respondents. For "T-shirt 11" has the highest mean of 49.82 (=99.6\%). Subsequently, it followed by T-shirt 7 and T-shirt 6. However, T-shirt 3 has the lowest mean which 45.40 $(=90.8 \%)$.

As shown in Table 2, $\mathrm{F}=5.916 ; \mathrm{p}=0.000$. The differences according to respondents regarding the reading frequency of and the importance assign to various design. It was found that there is a statistical significance which confirms the research aim 'creating printing designs which reflect the ethical fashion values and concepts on proper $\mathrm{T}$-shirts for women, which improve the consumers' awareness and change his purchasing behavior to be more ethically' is achieved.

\section{CONCLUSION}

This research provided an overview for ethics in the fashion. It was grounded on environmental and social ethics and value discussion in it. As Niinimäki [18] argued "Products have to offer those values that are important to consumers". Ethical consumerism and corporate social and environmental responsibility will play significant roles in achieving an ethical fashion. The ethical issues raised surrounding the fashion industry have drawn intensive public interest among consumers. The relationship between consumers' awareness and purchasing behavior has been proved to be the most important aspect of developing ethical fashion.

According to data analysis, the questionnaire Items were positive with an overall mean score of 4.88 (\% of mean = $97.6 \%$ ). The majority of respondents agreed to with $11 \mathrm{~T}$ shirts. "T-shirt 11" has the highest mean of 49.82 (=99.6\%). Subsequently, it followed by T-shirt 7 and T-shirt 6 . However, T-shirt 3 has the lowest mean which was 45.40 (=90.8\%).

By using Statistical analysis of respondent's opinions, it was found that there are differences of statistical significances which confirms that the research aim "creating printing designs which reflect the ethical fashion values and concepts on proper T-shirts for women, improve the consumers' awareness and change his purchasing behavior to be more ethically" is achieved.

\section{REFERENCES}

[1] Favier, M. (2013). Consumer attitude and behavior in the ethical fashion industry. (Unpublished master's thesis). University of Kassel, Kassel, Germany.

[2] Solomon, M., Bamossy, G., Askegaard S., \& Hogg, M. (2010). Consumer behavior: a European perspective. 4th ed. Pearson Education, Harlow, England.
https://doi.org/10.47001/IRJIET/2020.407007

[3] Shaw, D. \& Shiu, E. (2003). Ethics in consumer choice: a multivariate modelling approach. European Journal of Marketing, Vol. 37 (10), 1485-1498.

[4] Allwood, J.M., S.E. Laursen, C. Malvido de Rodriguez, \& Bocken, N. (2006) well dressed? The Present and Future Sustainability of Clothing and Textiles in the United Kingdom. Cambridge, UK: University of Cambridge Institute for Manufacturing.

[5] Hethorn, J. \& Ulasewicz, C. (2008). Sustainable Fashion, Why Now? New York: Fairchild Books.

[6] Kozlowski, A., Bardecki, M., \& Searcy, C. (2012). Environmental impacts in the fashion industry: A life-cycle and stakeholder framework. Journal of Corporate Citizenship, (45), 17-36.

[7] Perry, P. \& Towers, N. (2012). Conceptual framework development: CSR implementation in fashion supply chains. International Journal of Physical Distribution \& Logistics Management, Vol. $43(5 / 6), 478-500$.

[8] Pollari, M. (2017). Consumer's Purchase Intention of Ethical Fashion - Examining beliefs about fashion industry and attitudes towards ethical fashion (Master's thesis). University of Turku. Turku: UTU Publications. Retrieved from http://www.utupub.fi/handle/10024/144287

[9] Schaefer. A., Crane, A. (2005). Addressing sustainability and consumption. Journal of Macromarketing, 25, 76-92.

[10] Dielemans, E., \&Zanni, M. (2012). Ethical Fashion Consumerism: A Segmentation and Understanding of Young Swedish Consumers, Lunds University, School of Economics and Management, MSc International Marketing and Brand Management.

[11] Joergens, C. (2006). Ethical fashion: myth or future trend?. Journal of Fashion Marketing \& Management, Vol. 10(3), 360-371.

[12] Ethical Fashion Forum [EFF]. (2014). "Our mission." Ethical Fashion Forum. http://www.ethicalfashionforum.com/about-eff/ourmission. (Accessed October 23, 2019).

[13] Poldner, K. (2013). Un-dress: Stories of Ethical Fashion Entrepreneuring, Doctoral dissertation, University of St. Gallen.

[14] Shaw, D., Grehan, E., Shiu, E., Hassan, L. \& Thomson, J. (2005). An Exploration of Values in Ethical Consumer Decision Making, Journal of Consumer Behaviour, Vol. 4 (3): 185-200.

[15] James, A. (2015) Influencing Ethical Fashion Consumer Behaviour: A Study of UK High Street Retailers. Doctoral thesis, Northumbria University.

[16] Carrigan, M., \& Attalla, A. (2001). The myth of the ethical consumer-do ethics matter in purchase 
ISSN (online): 2581-3048

Volume 4, Issue 7, pp 40-52, July-2020

behaviour? Journal of consumer marketing, 18(7), 560-578.

[17] Newholm, T. \& Shaw, D. (2007) Studying the Ethical Consumer: A Review of Research. Journal of Consumer Behaviour, 6, pp. 253 - 270.

[18] Niinimaki, K. (2010). Eco-Clothing, Consumer Identity and Ideology. Sustainable Development, 18, pp. 150-162.

[19] Teotia, V. (2018). Ethical consumerism in India: factors influencing Indian consumer's intention to purchase and continue the purchase of ethical clothing. (Master's thesis), University of Twente.

[20] Davies, C. (2007). Branding the Ethical Consumer, The Financial Times, 21 February.

[21] Szmigin, I., Carrigan, M. \&Mceachern, G. (2009). The Conscious Consumer: Taking a Flexible Approach to Ethical Behaviour. International Journal of Consumer Studies, pp. 224 - 231.

[22] Paulins, V. \& Hillery, J. (2009). Ethics in the Fashion Industry, Fairchild Books, New York, NY.
https://doi.org/10.47001/IRJIET/2020.407007

[23] IISD. (2013). Who Are the Green Consumers? Retrieved October 25, 2019, from https://www.iisd.org/business/markets/green_who.as px

[24] Churchill, G., \& Iacobucci, D. (2002). Marketing research: Methodological foundations (8th ed.). Orlando, Florida, United States of America: Harcourt College Publishers.

\section{AUTHOR'S BIOGRAPHIES}

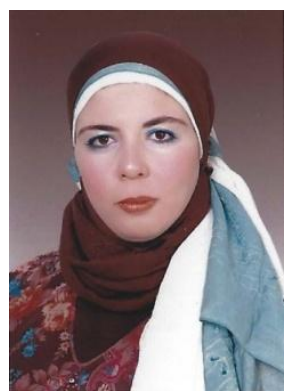

Olfat Shawki Mohamed Mansour Professor, Apparel Department, Helwan University, Cairo, Egypt. Associate professor, Fashion Design Department, Qassim University, Buraidah, Saudi Arabia. E-mail: o.mansour@qu.edu.sa ORCID ID: https://orcid.org/00000002-1205-2452

\section{APPENDIX-1}

\begin{tabular}{|c|c|c|c|c|c|c|}
\hline \multirow[b]{2}{*}{ No } & \multirow[b]{2}{*}{ Items } & \multicolumn{5}{|c|}{ Design $(. . . . .)}$. \\
\hline & & 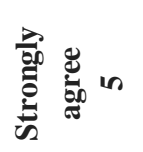 & 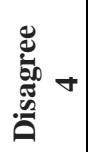 & 恶 & 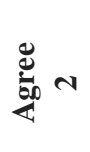 & 常 \\
\hline 1 & $\begin{array}{l}\text { The ethical value in the printing design helped me to understand } \\
\text { more about ethical fashion. }\end{array}$ & & & & & \\
\hline 2 & $\begin{array}{l}\text { I believe that the printing design is a message which encourages } \\
\text { anyone to buy ethical fashion. }\end{array}$ & & & & & \\
\hline 3 & $\begin{array}{l}\text { I believe that the printing design succeeded in informing me about } \\
\text { ethical issues in the fashion manufacturing. }\end{array}$ & & & & & \\
\hline 4 & $\begin{array}{l}\text { The materials used which generally clearly stated on the T-shirt tag } \\
\text { confirmed me that the using of organic and sustainable fabrics } \\
\text { reduce negative impacts on environment. }\end{array}$ & & & & & \\
\hline 5 & $\begin{array}{l}\text { I believe that I am informed about environmental and social issues } \\
\text { through the ethical values that the printing design carry. }\end{array}$ & & & & & \\
\hline 6 & $\begin{array}{l}\text { Buying ethical fashion is a good thing because it positively affects } \\
\text { society and environment. }\end{array}$ & & & & & \\
\hline 7 & $\begin{array}{l}\text { After understanding the ethical values that the T-shirt carry, Next } \\
\text { time when I buy clothes, I will rather buy the ethically produced } \\
\text { option. }\end{array}$ & & & & & \\
\hline 8 & $\begin{array}{l}\text { The printing design elements (symbols, colours, and Explanatory } \\
\text { statements) helped me in understandingthe ethical fashion values. }\end{array}$ & & & & & \\
\hline 9 & $\begin{array}{l}\text { The printing design helped in creating a favourable attitude towards } \\
\text { ethical clothing. }\end{array}$ & & & & & \\
\hline 10 & $\begin{array}{l}\text { Ethical issues that the printing design carry, improved my } \\
\text { awareness toward the ethical fashion. }\end{array}$ & & & & & \\
\hline 11 & $\begin{array}{l}\text { After understanding the ethical values that the printing design } \\
\text { carry, I believe that by purchasing an item of ethical clothing, I } \\
\text { could make a difference to the fashion negative impacts on society } \\
\text { and environment. }\end{array}$ & & & & & \\
\hline
\end{tabular}


Citation of this Article:

Olfat Shawki Mohamed Mansour, "Creating Designs to Improve Consumer's Awareness and Purchasing Behavior towards Ethical Fashion" Published in International Research Journal of Innovations in Engineering and Technology - IRJIET, Volume 4, Issue 7, pp 40-52, July 2020. https://doi.org/10.47001/IRJIET/2020.407007

$* * * * * * *$ 